\title{
AN OUTBREAK OF HYSTERICAL PARAPLEGIA
}

\author{
By Norval Watson, M.B., CH.B., D.P.H. \\ Lodge Moor Hospital, Sheffield, England
}

\begin{abstract}
The diagnosis of hysterical paraplegia, following injury, has only rarely been made, and no report of such cases has been recorded in the recent textbooks by Guttmann, Bedbrook and other authors. In a review of non-traumatic paraplegia, treated at the Sheffield Unit, the diagnosis was not made during a period of 15 years, until the winter of $1977 / 78$ when four such cases were confidently recognised in a short period of time. This surprising development encouraged me to review these cases to ascertain whether there were any common factors to explain such an unusual outbreak. The patients were all young men engaged in heavy physical work and other circumstances common to most of them were service in a uniformed organisation; with psychiatric illness, and marriage breakdown as principal features. Fortunately recovery was rapid and complete in most cases.

I have no references to list as I could not find any reports of similar cases in the paraplegic and psychiatric literature.
\end{abstract}

Addendum. Since this paper was read in July I98I, two further cases of hysterical paraplegia have been detected, both dissimilar in almost every feature from the four cases reported.

Key words: Hysteria; Paraplegia.

I PRESENTED a paper on nontraumatic paraplegia to the International Medical Society of Paraplegia in Holland in 1980, and of the total of 655 cases, I noted that seven of these were due to hysterical paralysis. Further, I reported that, whereas two of these seven cases appeared in 1950 and one in 1963 , the remaining four presented to the unit within a 3 -month period in 1978 , almost an epidemic. It seemed strange that nearly I 5 years could elapse without a single case of hysteria and then four should present in a short period of time. The four cases were similar in that they were all young men in their prime, engaged in heavy physical work. I therefore decided to study the four case histories to elucidate any other common factors and to try to establish the reason why they should all present in the same winter.

Case No. I was a young man of 2I years who had worked as a deep-sea diver for 2 years. He had experienced one previous episode of the 'bends' with cerebral symptoms of slurred speech and incoordination lasting 30 minutes with recompression. In October I977 he spent 3 days diving in the Persian Gulf. Twelve hours after his last dive while drinking ashore he felt tingling in his legs. He was recompressed intermittently during the next 4 days but his legs became completely paralysed, with loss of sensation below the knees. However, he was able to pass urine. He was transferred back to the U.K. to a naval hospital and then to a Manchester hospital where his wife was in the late stages of pregnancy. He was seen by several specialists who gave rather a poor prognosis. On the same day that the baby was born he began to move his legs. I saw him at that time and found weak voluntary power grade 3 in all muscle groups, with some patchy sensory loss below the knees. His reflexes were normal and a confident diagnosis of hysterical paralysis was made. By the time he was transferred to Sheffield 2 days later 
there was no neurological deficit. When he was informed of my diagnosis he discharged himself from hospital the same day, not only walking normally but carrving all his diving equipment to the bus stop. $\mathrm{He}$ had a psychiatric history of depression with alcohol addiction treated in several hospitals. Two months later he was in prison and his marriage had broken up.

Case No. 2 was a young man of 28 years who was involved in a road accident in December I 977 when his car overturned. He was admitted to hospital unable to move his legs but $\mathrm{X}$-ray showed no bone injury. He complained of pain over the whole of his back but there was no local tenderness. Neurological examination disclosed that, although he alleged that he could not move his legs, when he was turned over he could hold his legs up to prevent them falling off the bed. Sensory loss was patchy and bizarre and all the reflexes were normal. He was able to pass urine normally. During the next week power returned slowly to his legs and he was got up to stand and walk but even after his legs regained full power he walked with an awkward gait.

His left hand had been injured in a steel works 9 months previously when no fractures were seen on X-ray. He alleged that he could not move the 3 rd, 4 th and 5 th fingers of the hand, with loss of sensation over them. He had consulted several orthopaedists and had instituted claims for disablement. He could not move these three fingers but when blood was taken from his arm he clenched his fist normally. He even did weight lifting in the gym. His past history revealed that he had been a policeman but had left the force. He had a bad social background and had been divorced.

Case No. 3 was a 30-year-old lorry driver who was reputed to have been thrown through the windscreen when his lorry skidded and overturned. He alleged that the lorry struck him on the back. He dragged himself to the side of the road where he was found I hour later. He was taken to hospital and subsequently transferred to a Spinal Injuries Unit with a complete paraplegia below the Dro level. Plain X-rays of his spine and a myelogram were normal. He was able to pass urine for 3 days but then needed catheterisation for a month. He alleged that he was completely paralysed for 3 weeks but then noticed some recovery. On admission to Lodge Moor 6 weeks after injury examination revealed a bizarre pattern of weakness of the legs, with apparent complete sensory loss below Dio. His reflexes were normal. He was able to turn himself over in bed very easily and could dress and transfer himself much better than could be expected from his neurological deficit. We removed his catheter and he passed urine normally, refusing to allow a residual test. I considered him to be hysterical. He was allowed up to attempt walking, which he did with some difficulty but never returned to hospital after his first week-end leave. I saw him again 2 years later after another injury when he alleged that he had been knocked down by a car deliberately. He again had weakness for 3 weeks with full recovery.

This man had been in the army and served in Northern Ireland where he claimed he was in the S.A.S. regiment. He boasted about his exploits, which no true S.A.S. soldier would ever do. In the ward he told the staff and other patients not to approach him from behind nor surprise him as he had been trained to react quickly and might injure or kill them at a stroke. He had two broken marriages.

Case No. 4 was a 25-year-old miner who was involved in a mining accident early in I978, when he was buried by a roof fall. He was admitted to hospital where he alleged paralysis and loss of sensation in the right leg and 4 days later in the left leg. But the hospital notes recorded normal movements of both legs and X-ray of the spine was normal. He said that he could pass urine only with the aid of injections. He was transferred to Lodge Moor in the third week, by which time he had begun to recover power grade 3 in the legs but still alleged loss of sensation from Di2 to S2, with normal perineal sensation $S_{3}, 4$, 5. Although he alleged loss of sensation, his coordination was normal at the feet and the reflexes were normal. He was obviously hysterical and was got up to walk with sticks. Even at discharge 5 weeks after injury he still claimed 
anaesthesia from $\mathrm{L}_{2}-\mathrm{S}_{2}$ and 2 months later he still used sticks to walk a half-mile. At 6 months he was back at light work, walking normally but still claiming impaired lumbar sensation on front of thighs.

He had been a regular soldier and was wounded in the shoulder in Northern Ireland in I977. He has a broken marriage. He had a psychiatric background going back to I973 with two episodes of drug overdosage in I973 and I978.

\section{Discussion}

Apart from the remarkable coincidence of four cases of hysterical paraplegia within one winter period (there having been only one other case in the previous 25 years), several points of similarity were evident in the four cases. All were young men in the 20-30 age group, engaged in heavy physical work. Three had been members of uniformed services, two in the army and one in the police. The other was a deep-sea diver, an occupation in which discipline is paramount, as if in a uniformed service. The two ex-soldiers had served in Northern Ireland, where one had been shot and the other engaged in cloak-and-dagger activities according to his own account. All four had been divorced following breakdown of their marriages and two had long psychiatric histories with addiction to alcohol or drugs. One could be classed as a malingerer but he was so naive in his presentation that he was easily detectable and therefore probably hysterical. The third case had a bizarre aggressive manner, quite remote from normal conduct.

Most cases of hysterical paralysis or anaesthesia occur in young women and can usually be detected, the symptoms and signs being at variance with the correct anatomical patterns of neurological deficit.

Traumatic neurosis on the other hand is mostly male and tends to be associated with injury in the industrial field or in transport with a large element of compensation involved. If this is not the case then some form of psychological dividend is sought or an escape from an intolerable situation at work. The view has been expressed that trauma does not lead to neurosis but that it is the exploitation of a history of trauma which is the method of development of their ill-health. The trauma is but the scapegoat for the expression of their long-standing psychoneurosis.

Hysterical paraplegia is not recorded by Guttmann, Bedbrook and other authors of books on spinal injuries so that we can assume that the condition is rare. It is unusual therefore to record four such cases in one short winter season.

\section{SUMMARY}

Only seven cases of hysterical paraplegia were identified out of 2000 admissions to the Sheffield Unit over a period of 30 years but interestingly four of these were admitted over a very short interval in 1977/78. They all had common features, including recent Army service, psychiatric backgrounds and broken marriages. No other cases of this type have been identified before or since.

\section{RÉSUMÉ}

Seulement sept cas de paraplègié hystérique étaient identifié hors de deux mille hospitalisés au Unité de Sheffield pendant un espace de temps de 30 ans mais, d'une manière intéressante, quatre de ces sept cas étient en Hopital pendant une periode trés courte en I977/78. Ils ont eu les grands traits en commun, y compris le service militaire récemment, un fond histoire psychiatrique ou la dissolution d'un mariage. Il n'y a pas des autres cas de se genre identifie avant on depuis ce temps là. 
ZUSAMMENFASSUNG

Unter 2000 Aufnahmen in die Sheffielder Abteilung während einer Periode von 30 Jahren wurden nur 7 Falle hysterischer Paraplegie entdeckt. Interessanterweise fallen 4 dieser Fälle in einen kurzen Zeitabschnitt in 1977/78. Alle hatten gewisse Symptome geneinsam, z.b. kürzlichen Militärdienst, psychiatrische Anamnese und zerrüttete Ehen. Weder vor dieser Periode noch nachher wurden Fälle solchen Typs identifiziert. 